\title{
OPEN Agricultural land use curbs exotic invasion but sustains native plant diversity at intermediate levels
}

\author{
E. Pellegrini ${ }^{1,2 \bowtie}$, M. Buccheri ${ }^{3}$, F. Martini ${ }^{4} \&$ F. Boscutti ${ }^{2}$
}

Unveiling the processes driving exotic plant invasion represent a central issue in taking decisions aimed at constraining the loss of biodiversity and related ecosystem services. The invasion success is often linked to anthropogenic land uses and warming due to climate change. We studied the responses of native versus casual and naturalised exotic species richness to land uses and climate at the landscape level, relying on a large floristic survey undertaken in North - Eastern Italy. Both climate and land use drove exotic species richness. Our results suggest that the success of plant invasion at this scale is mainly due to warm climatic conditions and the extent of urban and agricultural land, but with different effects on casual and naturalized exotic species. The occurrence of non-linear trends showed that a small percentage of extensive agricultural land in the landscape may concurrently reduce the number of exotic plant while sustaining native plant diversity. Plant invasion could be potentially limited by land management, mainly focusing on areas with extensive agricultural land use. A more conscientious land management is more and more commonly required by local administrations. According to our results, a shift of intensive to extensive agricultural land, by implementing green infrastructures, seems to be a win-win solution favouring native species while controlling the oversimplification of the flora due to plant invasion.

Biological invasion greatly impacts world biodiversity and ecosystem functionalities and services ${ }^{1,2}$. Invasive plants decrease local species diversity ${ }^{3}$, alter soil biota ${ }^{4}$, increase ecosystem productivity by altering nutrient cycling ${ }^{5,6}$ and impact landscape perception ${ }^{7}$.

Invasive alien species are widely studied in the literature ${ }^{3,8}$ but less is known about potentially future invaders. Exotic casual species and exotic naturalised species are plants that have not reached yet the ultimate "success stage" of the invasion". However, these two categories are extremely important in explaining plant invasion because they represent potentially future invasive species ${ }^{10}$. Casual species are of less concern because their spread is strictly linked to propagule pressure ${ }^{11}$. Instead, naturalised species are well-established species that can shed light on the invasion process even better than invasive plants because they represent the second to last stage of invasion. Predictions of naturalization are expected to be more robust than those for invasiveness and to be less site-specific ${ }^{12}$. In this light, comparing the distributions of casual and native exotics in relation to main environmental drivers might give novel insight into the future invasion scenarios.

The climate was originally proposed as the main filter for plant spread with cold temperatures limiting plant invasion ${ }^{13,14}$. However, the effect of climate on plant invasion is highly scale dependent ${ }^{15}$ and context-dependent ${ }^{16}$. Based on previous findings, invasive species could be favoured by the increase of temperatures due to climate change ${ }^{17,18}$ because of their phenotypic plasticity ${ }^{19}$, but with local environmental conditions affecting significantly this main trend ${ }^{20}$. Invasive species have demonstrated to adapt locally and to quickly evolve during expansion ${ }^{21}$ and ecosystem disturbance was considered more important than climate in the plant invasion process in the Mediterranean basin ${ }^{20,22}$. In fact, climate is fundamental for the progression of the invasion ${ }^{12}$ but exceptions can be explained by site-specific and human related factors, as an effect of an explicit interplay of such factors across the space ${ }^{15}$. Human activities were found to be responsible for enhancing biological invasion especially by increasing propagule pressure ${ }^{23,24}$. Roads, cities, crops and abandoned areas in particular represent primary sources for propagule dispersion ${ }^{25,26}$ because of landscape fragmentation ${ }^{27}$ and habitat vulnerability especially at the ecotone areas ${ }^{28}$. Urbanization is known to cause changes in plant biodiversity because of fragmentation, loss of suitable habitats and increased of pollution ${ }^{29}$. Abandoned agricultural lands remain preferential sites for

${ }^{1}$ Freshwater Biological Laboratory, Department of Biology, University of Copenhagen, Universitetsparken 4, 3rd floor, 2100 Copenhagen, Denmark. ${ }^{2}$ Department of Agricultural, Food, Environmental and Animal Sciences, University of Udine, via delle Scienze 91, 33100 Udine, Italy. ${ }^{3}$ Museo Friulano di Storia Naturale di Udine, via Cecilia Gradenigo Sabbadini, 22-32, 33100 Udine, Italy. ${ }^{4}$ Trieste, Italy ${ }^{\bowtie}$ email: elisa.pellegrini@bio.ku.dk 
invasion even after many years from the ceased of agricultural activities ${ }^{30}$. Semi-natural habitats are usually more resistant to plant invasion ${ }^{23,31}$ and a different landscape composition and disturbance seem to determine their degree of invasion ${ }^{32}$. In human-influenced landscapes, exotic species benefit from the increased soil fertility and soil disturbance ${ }^{14}$ but agriculture could also act as a buffer against plant invasion ${ }^{27,33}$. For these reason, the role of agricultural areas in plant invasion has still to be cleared, considering agricultural land use intensity (i.e. rate of crop area vs. linear small patches of semi natural vegetation) as a possible driver of the process.

Plant invasion has been proved to be linked to landscape heterogeneity ${ }^{27,34}$. However, most of the studies on invasive species used fine spatial scales that are seriously affected by biogeographical and historical processes ${ }^{35,36}$. Despite some studies already disentailed the impacts of climate from those attributed to land use $\mathrm{s}^{14,33,37,38}$, more rarely a distinction is provided between native species, exotic naturalised and exotic casual species. A nice example is provided by Marini et al. ${ }^{39}$ which showed a clear difference in species richness of exotic naturalised species and exotic casual species towards the increase of mean annual temperature.

Therefore, in the present work, the main objectives addressed were (1) to detect the impact of climate and land-use on species richness of exotics and (2) to highlight the possible different responses of exotic casual, exotic naturalised or native species at the landscape scale. As a novelty we considered the effects of different intensity of agricultural land on different categories of exotic species, showing an increasing level of risk in terms of plant invasion (naturalised species > casual species). We expected to find a contrasting response of native versus exotic species and, within exotics, of casual versus naturalised species. In particular, we expect exotics to be favoured by high temperature, precipitation and anthropic land uses cover, with casual exotic more associated to urban land use and roads, considered as main foci of exotic propagules. Moreover, we expected a different impact of intensive and extensive agricultural land use on plant invasion with casual species being less affected by the intensification of agriculture compared to naturalised exotic species. The study area (i.e. Friuli Venezia Giulia, Northern East of Italy) was selected as representing wide ecological gradients in terms of altitude, climate and land use intensity, and on the availability of a solid and updated floristic dataset for the area, useful to test the formulated hypotheses.

\section{Results}

Species richness. Alien flora counted 337 species and represented the $15 \%$ of the total species (alien plus native) recorded in Friuli Venezia-Giulia (Martini et al. in preparation). Among alien flora, casual (180) and naturalised species (120) were the most abundant, followed by invasive species (37) that represented the $11 \%$ of the exotic flora (for further details see ${ }^{40}$ ). Within each sample area, the number of casual and naturalised species ranged from 0 to 43 (mean \pm sd; $4 \pm 6$ ) and from 1 to 113 (41 \pm 25 ), respectively, while native species ranges from 150 to 1207 (603 \pm 181 ). Species richness of natives was higher in the Prealp and Karst areas (Fig. 1c), while the richness of naturalised exotic (Fig. 1d) and casual exotic species (Fig. 1e) peaked in the lowlands, Karst area and close to the main towns. Most of the alien species were perennial plants (35\% for casual exotic species, $26 \%$ for naturalised exotic species), out of these $30 \%$ were woody species (trees, shrubs) (17\% for casual, $13 \%$ for naturalised) and $31 \%$ were grasses or forbs (18\% for casual, $14 \%$ for naturalised). Annual species represent the $38 \%$ of the exotic flora, out of these $18 \%$ were casual exotic and $20 \%$ were naturalised exotic species. The most frequent exotic taxa were Erigeron annuus (frequency $=0.89)$, Erigeron canadensis $(0.77)$, Veronica persica $(0.77)$, Robinia pseudoacacia (0.74), Helianthus tuberosus (0.74), Artemisia verlotiorum (0.72) and Oxalis fontana (0.71).

Climate and land use as drivers of exotic species richness. Multi Model Inference analysis returned the full model as the only one plausible model (Table 1, Supplementary material Table S1) showing that all climate and land use variables were significant variables explaining species richness of natural, casual and naturalised exotic species (Fig. 2, Supplementary material Table S2). The model explained 69\% of the total variation.

Regarding land use, urban areas (including road network) drove the increase of both casual and naturalised exotic species while decreasing native species richness at largest covers (Fig. 2a).

Intensive agricultural land affected negatively both native and casual exotic species richness while exotic naturalised species were almost constant (Fig. 2c).

Extensive agricultural land showed consistent hump-shaped relationships with all considered species pools (Fig. 2e). Nonetheless, species richness of naturalised exotics increased with the increase of extensive agricultural land, with a peak at about $40 \%$ presence of extensive agricultural land, while native species showed a maximum value at about $20 \%$ of the landscape covered by this land use. Finally, casual species were favoured by intermediate cover of extensive agricultural area (about $30 \%$ of cover).

Regarding climate, naturalised exotic species were high at moderate rainfall and high monthly mean temperatures (Fig. 2b,d). Instead, native species increased along with the increase of rainfall and were not substantially influenced by temperature. Casual species follow the trend of naturalised species regarding temperature but were not influenced by rainfall.

\section{Discussion}

Plant invasion is expected to be boosted by climate change ${ }^{17,20}$ and by soil disturbance induced by anthropic land uses ${ }^{41,42}$. In the present work, both climate and land use drove exotic species richness, showing contrasting responses for native species. Our results suggest that the success of plant invasion at the landscape scale is mainly due to the spread of urban and agricultural land use while the occurrence of a small percentage of extensive agriculture (about 20\%) may reduce the number of exotic plant and promote native plant diversity.

The percentage of exotic species recorded in the present work is consistent with that reported for Italy, which is about $16 \%{ }^{43}$. Except for Robinia pseudoacacia, species with larger frequency were herbaceous plants, most of them annuals and belonging to the Asteraceae family. This family is the largest among flowering plants ${ }^{44}$ and 
(a)

(b)
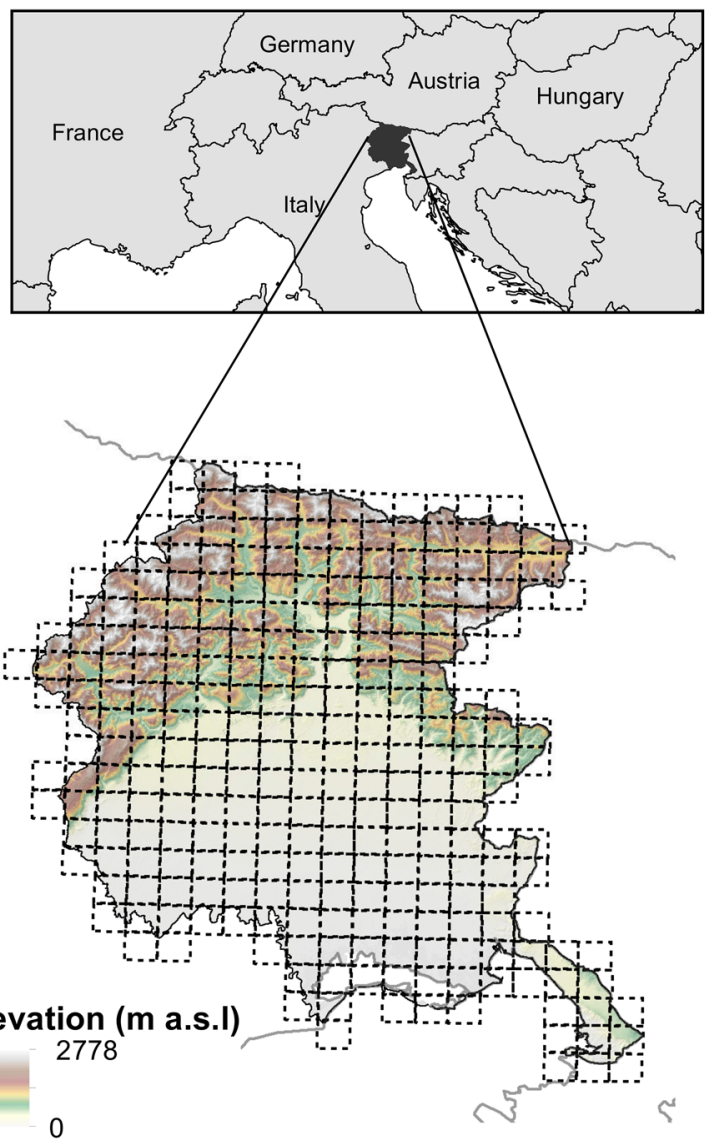

(d) casual exotics

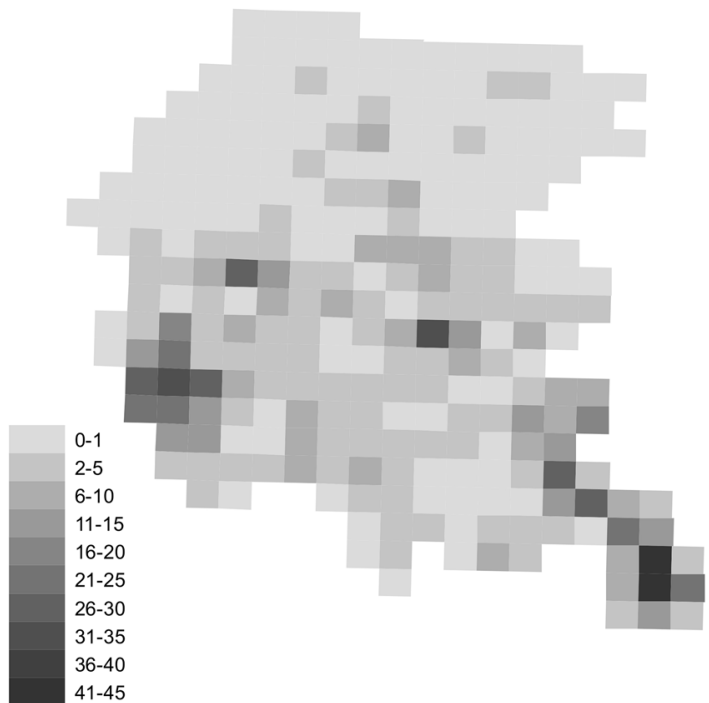

(e) naturalised exotics

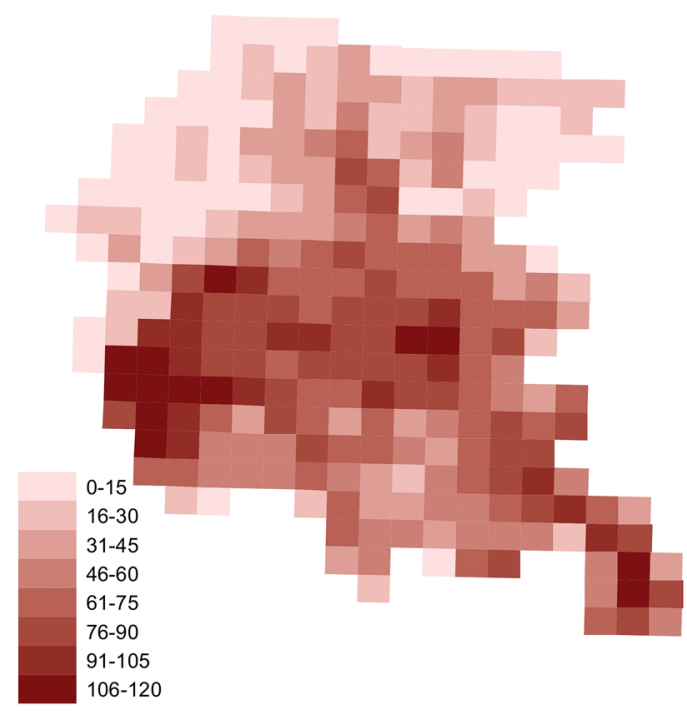

Figure 1. Location of the study area (a) and species richness in each grid cell of the three categories of native (c), casual exotic (d) and naturalised exotic species (e). Changes in elevation in the study area and position of grid cells based on the Central European grid for floristic surveys are also reported (b). Figure was realised using ArcGIS 10.0 (ESRI). 


\begin{tabular}{|l|l|r|c|}
\hline & DF & F & P \\
\hline Status & 2,36 & 36.00 & $<0.001$ \\
\hline Extensive agricultural land & 2,36 & 8.11 & $<0.001$ \\
\hline Intensive agricultural land & 2,36 & 14.84 & $<0.001$ \\
\hline Urban land & 2,36 & 35.25 & $<0.001$ \\
\hline Mean rainfall & 2,36 & 3.41 & 0.03 \\
\hline Mean temperature & 2,36 & 2.82 & 0.06 \\
\hline Extensive agricultural land: status & 4,36 & 88.06 & $<0.001$ \\
\hline Intensive agricultural land: status & 4,36 & 54.93 & $<0.001$ \\
\hline Urban land: status & 4,36 & 27.31 & $<0.001$ \\
\hline Mean rainfall: status & 4,36 & 4.50 & 0.002 \\
\hline Mean temperature: status & 4,36 & 2.84 & 0.02 \\
\hline
\end{tabular}

Table 1. LMMs results obtained for the best selected model after Multi Model Inference analysis. Status referred to natural, casual or naturalised exotic species. Degree of freedom (DF), F value of the statistic (F) and significance level $(\mathrm{P})$ are reported.

often associated to most successful invasive species ${ }^{24}$. Annual exotic species has been demonstrated to be highly competitive under anthropogenic disturbance regime ${ }^{26}$. Among the most frequent perennial woody plants many $\mathrm{N}$-fixer species were found (e.g. R. pseudoacacia, Amorpha fruticosa), showing to be an impacting life-form ${ }^{5}$, able to change ecosystem proprieties and plant diversity of the invaded ecosystems ${ }^{6}$.

There is no clear agreement among main factors favouring exotic species richness or spread. Some authors strongly support the role of biological traits ${ }^{45}$, phenology ${ }^{46}$ or historical factors about invasion success ${ }^{47}$. Factors affecting plant invasion play an important role at local scale while at large-scale (i.e. landscape), land-use and other large-scale processes (e.g. climate) can hide the local variations of soil and stand structure ${ }^{48}$. Climate and land use were commonly considered as well, but usually focusing on one single species or a specific environment ${ }^{49,50}$.

Precipitation and temperature were already proved to be main driver for plant diversity. It was proposed by the general climate-based hypotheses of plant richness distribution, which theory is based on water-energy dynamics ${ }^{51,52}$. Exotic species were limited in more humid (large mean rainfall) and cold areas, which refer to the alpine and mountain areas ${ }^{40}$, whereas native species were favoured by larger mean rainfall, as proved also for richness of endemic species ${ }^{53}$. Exotic species were found to be related to intermediate precipitation regimes. This behaviour is consistent with the hypotheses that exotic species are particularly sensitive to harsh conditions (e.g. drought stress), preferring intermediate environmental conditions ${ }^{54,55}$.

Literature already demonstrated a contrasting response of native and exotic species in relation to temperature, showing the preference of exotic species for warmer temperatures ${ }^{39}$. The increase in temperature due to climate change is expected to increase exotic species richness and abundance ${ }^{17}$. Upon this view, predictions seem to be more severe into the Mediterranean area, due to a more effective establishment, growth and reproductive rates of exotics compared to the native Mediterranean species ${ }^{20}$. Our study seems to support such expectations, showing that exotic species were more strongly related to temperature rather than natives. However, casual and naturalised exotic species did not show a different pattern towards temperature. In this light, temperature (along with water availability) seems to act as a climatic filter on species, i.e. favouring the naturalization of species of warmer climates. Indeed, we found temperature to be strongly correlated to elevation. For this reason, we can argue about a synergic action of climate and other environmental factors related to elevation (e.g. light intensity, snow cover, nutrients availability) in limiting exotic species, as other studies relating plant invasion to elevation already pointed out ${ }^{56,57}$.

Besides climate, the number of exotic species is also associated with human land management ${ }^{58}$ and plant distribution depends on land use, especially where extreme abiotic gradients are missing ${ }^{59}$. In our dataset, the effect of land use on plant invasion seemed to better explain differences in species richness among native, casual exotic and naturalised exotic species compared to climatic variables, especially considering the shift in the maximum species richness of the three different categories towards extensive agricultural land use. The larger impact on plant invasion of land use, compared to climate, was already reported for the Mediterranean region ${ }^{20}$. Human made environments are more prone to invasion ${ }^{23,60,61}$ and several studies showed that semi-natural habitats are more easily invaded, especially when included in an urban or agricultural context ${ }^{26,62}$.

Cities represent a mosaic of human-made habitats easy to be invaded by exotic species ${ }^{24,31}$. Urban areas are key sites for first introduction and support the propagule pressure effect ${ }^{63,64}$. In our work, casual species were clearly favoured by urban areas and streets, because they have not overcome the reproductive barrier ${ }^{9}$ and their reproductive strategy is restricted on propagule pressure ${ }^{36,61}$. In this process, a particular role is played by main roads ${ }^{65}$, which in our study were included in the urban land use.

We recorded a strong and negative relationship between native species richness and farming (especially intensive farming), whereas the effect on exotic species seemed less strong (casual) or irrelevant (naturalised). Human-managed environments are widely recognised for favouring plant invasion ${ }^{24,26,61}$. Native plant species respond more negatively to agricultural intensification than exotics, probably due to the high soil nutrient availability, that in agricultural area is well represented by phosphorus ${ }^{66}$. Long-term application of chemical 
a

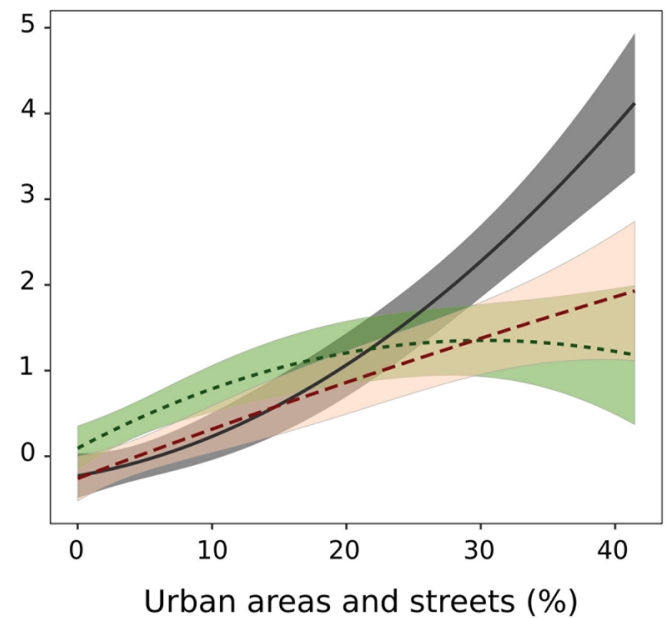

b

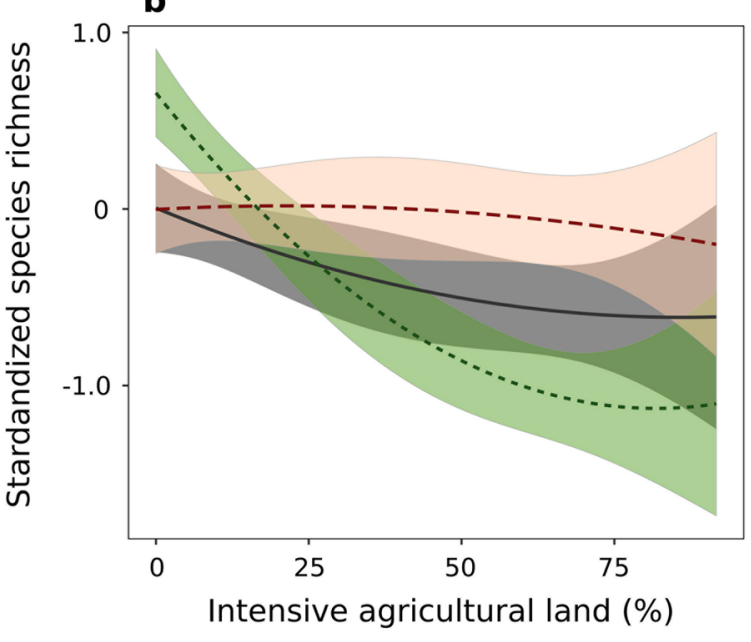

C

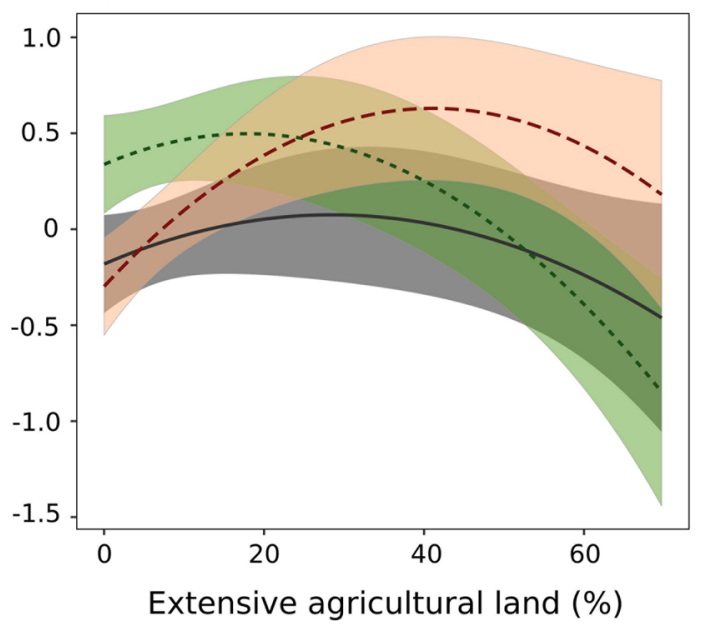

d

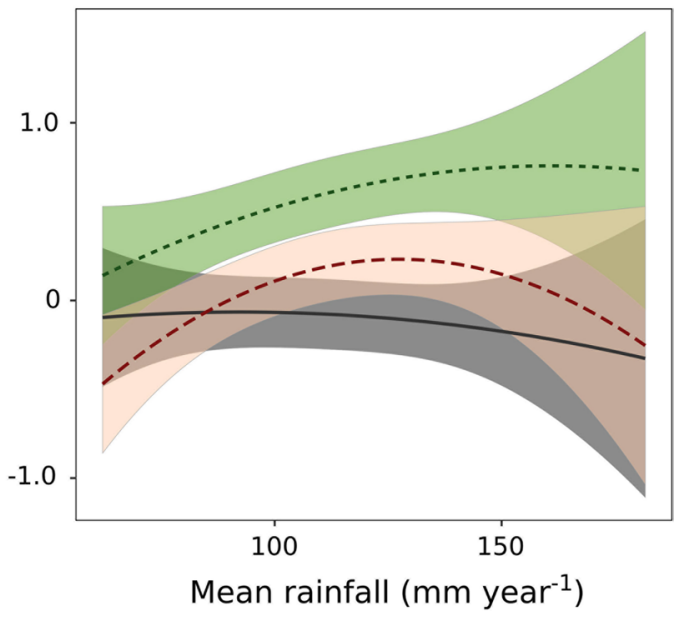

$\mathbf{e}$

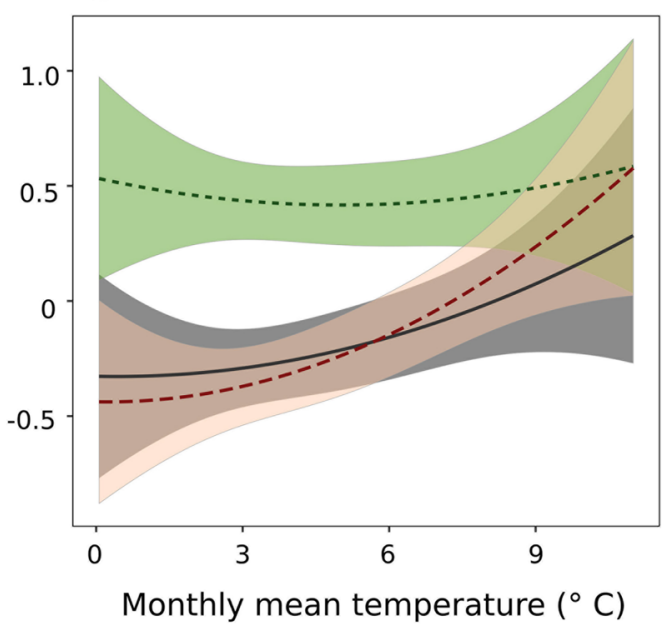

Monthly mean temperature $\left({ }^{\circ} \mathrm{C}\right)$

Figure 2. Best selected model using the Multi Model Inference analysis. The model $\left(A I C=0, R^{2}=0.69\right)$ shows the effects of urban $(\mathbf{a})$, intensive and extensive agriculture $(\mathbf{b}, \mathbf{c})$ land uses, annual rainfall $(\mathbf{d})$ and mean temperature (e) on native (dotted lines) and exotic (casual = solid lines, naturalised = dashed lines) standardised species richness. 
fertilizer may promote plant invasion ${ }^{12}$ and have long lasting effects on ecosystems $s^{67,68}$. In fact, small patches of natural habitat within the intensive agricultural land have been proved to be the last source of plant diversity in oversimplified agricultural lands but also a focus for weed plants ${ }^{69,70}$.

Intensification of agriculture causes dramatic decline in plant diversity, both to native and exotic species ${ }^{71}$, and affects critically the ecosystem functioning ${ }^{72}$. Nevertheless, at intermediate degree of soil disturbance, there is a positive relation between disturbance and invasion by exotic plants ${ }^{60}$. Anthropogenic disturbance in association with a large heterogeneity of the landscape was reported to promote species richness, of both native and exotic plants $^{73}$. The intermediate disturbance hypothesis is widely recognised and support the idea that intermediate levels of disturbance result in the highest levels of species richness ${ }^{74,75}$. Our work upheld the extension of such hypothesis to landscape disturbance processes, for which the pressure of extensive farming revealed different thresholds for the three different categories analysed, i.e. native, casual exotic or naturalised exotic species. The increasing percentage of extensive agricultural land corresponded to a different peak in species richness of natives (around $20 \%$ of extensive agricultural land), casual exotics (30\%) and naturalised exotics (40\%). Plant invasion has been also proved to be strictly linked to landscape heterogeneity ${ }^{34}$ and our study area comprised a wide range of ecosystems with large differences in climate, ecological conditions and land use. Extensive agricultural land comprises a larger heterogeneity of the landscape compared to the intensive agricultural land, including hedges and grassland sides, differences in land management and type of disturbance. Therefore, the land management on the extent of extensive agriculture, at the regional scale, could be potentially crucial for preserving native species and limiting plant invasion.

\section{Conclusion}

Our work showed that plant invasion is boosted at a landscape scale by increasing temperatures and large land use of extensive agriculture. However, a small area of extensive agriculture improves biodiversity of native plant species. A more conscientious land management is more and more commonly required by local administrations and, from our results, the reduction of extensive agricultural land seems to be a strategic choice for favouring native species while controlling the simplification of the flora due to plant invasion. A landscape perspective is necessary to face the challenge of maintaining productive lands while promoting biodiversity conservation and sustaining ecosystem services ${ }^{76}$. Our study suggests that a trade-off between productive purposes and environmental sustainable schemes might be a win-win solution not solely to sustain biodiversity but also to help the great effort of policies aimed at containing the biological invasion.

\section{Material and methods}

Study site. The study area was the Friuli Venezia-Giulia region (FVG, centroid coordinates $=46^{\circ} 24^{\prime} 00^{\prime \prime} \mathrm{N}$, $13^{\circ} 04^{\prime} 50^{\prime \prime}$ E, Fig. 1a). It covers an area of about $7900 \mathrm{~km}^{2}$ and is bounded by the Julian and Carnic Alps to the north, the Adriatic Sea to the south and the Karst of Trieste to the east. FVG exhibits a high geological and morphological complexity ${ }^{77}$, showing a prevalence of calcareous soils (i.e. limestone and dolomites) in the mountain region, alluvial calcareous deposits in the lowlands and the occurrence of both rock and sandy coasts ${ }^{77}$. FVG exhibits a continental climate in the inner valleys and temperate conditions in the outer area, with a mean annual air temperature of about $12{ }^{\circ} \mathrm{C}$. Due to its ecological complexity, FVG has been recognised for its considerable plant diversity since early botanical surveys ${ }^{78}$. The area encompasses several protected areas including wellconserved wetlands, grasslands and ancient woods. Landscape variability determines a large complexity of land uses, mainly dedicated to the intensive agriculture in the plain. In these cultivated areas both annual (maize, barley, soybean) and perennial crops (vineyards, orchards, poplar) are frequent ${ }^{79}$. FVG was selected as study area because of the occurrence of clear altitudinal and climatic gradients, ranging from the coast to the Alps and the strong impact of human land uses. Moreover, an intensive and updated floristic survey was conducted during the last 40 years resulting in a solid database of presence and location of native or exotic species (see below).

Plant species distribution. In the present study, FVG was divided in 273 cells (Fig. 1b) based on the Central European grid for floristic surveys ${ }^{80}$. Each grid cell was about $3^{\prime}$ of latitude $\times 5^{\prime}$ of longitude $(\mathrm{ca} .5 .5 \times 6.5 \mathrm{~km})$. Species distribution data relied on an ongoing survey aimed at creating a new vascular plant atlas for the FVG region (data from Martini F. and collaborators, for details see Acknowledgment section). The dataset has more than 290,000 records, including field data, herbarium specimens and literature data (period 1980-2020). The data were collected during a coordinated field sampling programme providing comparable and sufficient sampling effort in all the cells of the region (Supplementary material Fig. S1). The sampling effort in the different cells was related to the saturation level of the species accumulation curves, i.e. a cell was explored until the number of species tended to saturation.

The occurrence of taxa was recorded for each grid cell. Species were divided into 3 groups: native, casual exotic and naturalised exotic species. Naturalised exotic species included invasive species. Following the accepted framework for biological invasion ${ }^{9}$, a casual species overtakes the survival barrier whereas a naturalised species overcomes the following barriers of reproduction and dispersal. Nomenclature and taxonomy followed the Italian flora check-lists ${ }^{43,81}$. Exotic status (i.e. casual and naturalised species) was classified according to the regional check-list ${ }^{40}$. For each group, species richness was calculated for a total of 196 cells, excluding those at the border of the area showing incomplete data.

Environmental predictors. For each of the 196 cells, we calculated 7 environmental variables divided in geomorphological, climatic and land use predictors. Environmental data are reported in Table 2. 


\begin{tabular}{|c|c|c|c|}
\hline & Min & Mean & Max \\
\hline \multicolumn{4}{|l|}{ Geomorphology } \\
\hline Elevation $(\mathrm{m})$ & 0 & 529 & 1779 \\
\hline \multicolumn{4}{|l|}{ Climate } \\
\hline Monthly mean temperature $\left({ }^{\circ} \mathrm{C}\right)$ & 0.06 & 6.07 & 11.00 \\
\hline Mean rainfall $\left(\mathrm{mm} \mathrm{year}^{-1}\right)$ & 620 & 962 & 1817 \\
\hline \multicolumn{4}{|l|}{ Land use } \\
\hline Natural areas $(\%)$ & 0 & 47 & 100 \\
\hline Urban areas and streets (\%) & 0 & 7 & 41 \\
\hline Intensive agricultural land (\%) & 0 & 21 & 91 \\
\hline Extensive agricultural land (\%) & 0 & 13 & 69 \\
\hline
\end{tabular}

Table 2. Minimum ( $\min$ ), mean and maximum ( $\max$ ) values per cell grid for elevation, climate and land use data.

The geomorphological predictor selected was the elevation (m a.m.s.l.). Data were obtained from the Digital Elevation Model (DEM) of FVG based on $10 \mathrm{~m}$ resolution (IRDAT FVG, http://irdat.regione.fvg.it/). Elevation was in average $529 \mathrm{~m}$ a.m.s.l. ranging from 0 to 2,780 $\mathrm{m}$ (Coglians mountain).

Climatic data were obtained from the official climatic institute OSMER ARPA (https://www.osmer.fvg.it/) from a grid dataset of $500 \mathrm{~m}$ resolution. The mean monthly temperature $\left({ }^{\circ} \mathrm{C}\right)$ per grid cell refers to the annual average of mean monthly temperature in the period 1991-2010 and mean annual rainfall ( $\mathrm{mm}_{\text {year }}{ }^{-1}$ ) refers to the period 1961-2010. Monthly mean temperature was in average $6{ }^{\circ} \mathrm{C}$ and annual mean rainfall was $962 \mathrm{~mm}$.

Land use types were obtained from FVG Land Use cartography based on the maps derived by MOLAND project $(1: 25,000)^{82}$ and further updated and modified for ecological networking purposes (http://irdat.regione.fvg.it/ WebGIS/). Land use types were merged in 4 different categories: natural areas, urban areas and streets, intensive agricultural land and extensive agricultural land. Each category was expressed as the \% of surface occupied by a specific land use inside each grid cell. Natural areas included grasslands, woods and rivers. Urban areas and roads included cities and industrial areas and main road network. The agricultural areas were further divided in two categories, namely intensive and extensive agricultural land use, according to the rate between cropland (arable filed areas) and patches of linear and small semi-natural habitats not detected by scale map (i.e. ditches, grass strips, meadows, hedgerows) (Supplementary material Fig. S2). The mean crop cover within intensive versus extensive agricultural land use was preliminary assessed on 15 circular sample areas in agricultural landscapes of ca. $7.1 \mathrm{~km}^{2}$ (radius $=1.5 \mathrm{~km}$ ) where a detailed maps of ditches, grass strips, meadows, hedgerows was quantified. Intensive agricultural land was largely covered by annual and perennial crops (cropland mean $\pm \mathrm{sd}$; $95.1 \pm 4.0 \%)$ in very simplified crop rotations. Extensive agricultural land use included croplands $(66.8 \pm 13.8 \%)$ but also relevant patchworks of linear or small semi-natural habitats not detected by scale map (i.e. ditches, grass strips, meadows, hedgerows). Average values of variables were calculated for each grid cell using QGIS $2.18^{83}$.

Considering the whole cell grid, urban land cover was about $7 \%$ of each cell area on average. Extensive agricultural land was in average $13 \%$, reaching up to $69 \%$ of cover per cell. Intensive agricultural land was higher compared to extensive agricultural land, in average $21 \%$ and up to $91 \%$.

Data analysis. The influence of the considered environmental variables on species richness of native, casual exotic or naturalised exotic species was evaluated with a Multi-Model Inference approach. Prior to modelling, variables were examined for collinearity ${ }^{84}$ by Pearson's correlation test and by variance inflation factor using the 'vif' function ${ }^{85}$. Elevation was removed from the model because highly negatively correlated with the mean temperature $(\mathrm{r}=-0.79, p<0.001)$. Natural areas were not included in the model because complementary to the other land use types (Supplementary material Fig. S3).

We used Linear Mixed-effects Models (LMMs) to estimate model parameters. The model included species richness as response variable, the status (native, casual exotic or naturalised exotic species) as factor, climate and land use predictors as fixed effects. As the number of species of each exotic status (i.e. native, casual and naturalised exotic species) were quantified in the same cells, we included the id of sampling cell as a random factor to correct the number of degrees of freedom. We accounted for possible spatial correlation of data by including in the model the following semivariogram functions: exponential, Gaussian, linear, rational quadratic, and spherical. We used this method as one of the most robust application in ecological data ${ }^{86}$, all the used functions are detailed in Pinheiro and Bates ${ }^{87}$. We fitted the full model and compared all the possible combinations of semivariogram function and selected the best model using the Akaike Information Criterion (AIC). The model considering the rational semivariogram function was the best solution and hence considered in the further model selection.

The Multi-Model Inference analysis was carried-out using R statistical software ${ }^{88}$ with the 'MuMIn' package ${ }^{89}$. The LMMs were applied using the "nlme" package ${ }^{90}$. The analysis was carried out on a single model exploring the combined effect of species status and environmental variables.

For each variable, a quadratic term was included in order to consider possible non-linear responses. Within each status level (i.e. native, casual exotic, naturalised exotic), we standardised species richness using the $\mathrm{Z}$ standardization function.

Model assumptions were verified looking at diagnostic plot of the distribution of the residues. We used Akaike's information criterion (AIC) to select the best model (lowest $\Delta \mathrm{AIC}$ ) among all plausible models $(\Delta \mathrm{AIC}<2)^{91}$. 


\section{Data availability}

Authors declare that data will archived in a suitable and free repository according to the journal policy.

Received: 20 July 2020; Accepted: 30 March 2021

Published online: 16 April 2021

\section{References}

1. Simberloff, D. et al. Impacts of biological invasions: what's what and the way forward. Trends Ecol. Evol. 28, 58-66 (2013).

2. Vilà, M. \& Hulme, P. (eds) Impact of Biological Invasions on Ecosystem Services (Springer International Publishing, Berlin, 2017).

3. Gaertner, M., Den Breeyen, A., Hui, C. \& Richardson, D. M. Impacts of alien plant invasions on species richness in Mediterraneantype ecosystems: a meta-analysis. Prog. Phys. Geogr. Earth Environ. 33, 319-338 (2009).

4. Belnap, J., Phillips, S. L., Sherrod, S. K. \& Moldenke, A. Soil biota can change after exotic plant invasion: does this affect ecosystem processes?. Ecology 86, 3007-3017 (2005).

5. Liao, C. et al. Altered ecosystem carbon and nitrogen cycles by plant invasion: a meta-analysis. New Phytol. 177, 706-714 (2008).

6. Boscutti, F. et al. Cascading effects from plant to soil elucidate how the invasive Amorpha fruticosa L. impacts dry grasslands. J. Veg. Sci. 31(4), 667-677 (2020).

7. Pejchar, L. \& Mooney, H. A. Invasive species, ecosystem services and human well-being. Trends Ecol. Evol. 24, 497-504 (2009).

8. Vilà, M. \& Ibáñez, I. Plant invasions in the landscape. Landsc. Ecol. 26, 461-472 (2011).

9. Blackburn, T. M. et al. A proposed unified framework for biological invasions. Trends Ecol. Evol. 26(7), 333-339 (2011).

10. Kowarik, I. On the role of alien species in urban flora and vegetation. Plant invasions: general aspects and special problems. In SPB (eds Pysek, P. et al.) 85-103 (Academic Publishing, Amsterdam, 1995).

11. Hulme, P. E. Climate change and biological invasions: evidence, expectations, and response options. Biol. Rev. 92(3), 1297-1313 (2017).

12. Richardson, D. M. \& Pyšek, P. Naturalization of introduced plants: ecological drivers of biogeographical patterns. New Phytol. 196(2), 383-396 (2012).

13. Alexander, J. M. et al. Assembly of nonnative floras along elevational gradients explained by directional ecological filtering. Proc. Natl. Acad. Sci. 108, 656-661 (2011).

14. Hulme, P. E. Relative roles of life-form, land use and climate in recent dynamics of alien plant distributions in the British Isles. Weed Res. 49(1), 19-28 (2009).

15. Milbau, A., Stout, J. C., Graae, B. J. \& Nijs, I. A hierarchical framework for integrating invasibility experiments incorporating different factors and spatial scales. Biol. Invasions 11(4), 941-950 (2009).

16. González-Moreno, P., Diez, J. M., Ibáñez, I., Font, X. \& Vilà, M. Plant invasions are context-dependent: multiscale effects of climate, human activity and habitat. Divers. Distrib. 20(6), 720-731 (2014).

17. Bradley, B. A., Wilcove, D. S. \& Oppenheimer, M. Climate change increases risk of plant invasion in the Eastern United States. Biol. Invasions 12(6), 1855-1872 (2010).

18. Cao, Y., Zhang, S. \& Hu, W. Simulated warming enhances biological invasion of Solidago canadensis and Bidens frondosa by increasing reproductive investment and altering flowering phenology pattern. Sci. Rep. 8(1), 1-8 (2018).

19. Molina-Montenegro, M. A. \& Naya, D. E. Latitudinal patterns in phenotypic plasticity and fitness-related traits: assessing the climatic variability hypothesis (CVH) with an invasive plant species. PLoS ONE 7(10), e47620 (2012).

20. Gritti, E. S., Smith, B. \& Sykes, M. T. Vulnerability of Mediterranean Basin ecosystems to climate change and invasion by exotic plant species. J. Biogeogr. 33(1), 145-157 (2006).

21. Colautti, R. I. \& Barrett, S. C. Rapid adaptation to climate facilitates range expansion of an invasive plant. Science 342(6156), 364-366 (2013).

22. Vitti, S., Pellegrini, E., Casolo, V., Trotta, G. \& Boscutti, F. Contrasting responses of native and alien plant species to soil properties shed new light on the invasion of dune systems. J. Plant Ecol. 13, 667-675 (2020).

23. Vilà, M., Pino, J. \& Font, X. Regional assessment of plant invasions across different habitat types. J. Veg. Sci. 18, 35-42 (2007).

24. Lambdon, P. W. et al. Alien flora of Europe: species diversity, temporal trends, geographical patterns and research needs. Preslia 80, 101-149 (2008).

25. Botham, M. S. et al. Do urban areas act as foci for the spread of alien plant species? An assessment of temporal trends in the UK. Divers. Distrib. 15, 338-345 (2009).

26. Boscutti, F., Sigura, M., De Simone, S. \& Marini, L. Exotic plant invasion in agricultural landscapes: A matter of dispersal mode and disturbance intensity. Appl. Veget. Sci. 21(2), 250-257 (2018).

27. González-Moreno, P. et al. Quantifying the landscape influence on plant invasions in Mediterranean coastal habitats. Landsc. Ecol. 28(5), 891-903 (2013).

28. Catford, J. A., Vesk, P. A., White, M. D. \& Wintle, B. A. Hotspots of plant invasion predicted by propagule pressure and ecosystem characteristics. Divers. Distrib. 17(6), 1099-1110 (2011).

29. McKinney, M. L. Urbanization, biodiversity, and conservation. The impacts of urbanization on native species are poorly studied, but educating a highly urbanized human population about these impacts can greatly improve species conservation in all ecosystems. Bio. Sci. 52, 883-890 (2002).

30. Mattingly, W. B. \& Orrock, J. L. Historic land use influences contemporary establishment of invasive plant species. Oecologia 172(4), 1147-1157 (2013).

31. Chytrý, M. et al. Separating Habitat Invasibility by Alien Plants from the Actual Level of Invasion. Ecology 89, 1541-1553 (2008).

32. Jauni, M. \& Hyvönen, T. TInvasion level of alien plants in semi-natural agricultural habitats in boreal region. Agric. Ecosyst. Environ. 138, 109-115 (2010).

33. Carboni, M., Thuiller, W., Izzi, F. \& Acosta, A. Disentangling the relative effects of environmental versus human factors on the abundance of native and alien plant species in Mediterranean sandy shores. Divers. Distrib. 16(4), 537-546 (2010).

34. O'Reilly-Nugent, A. et al. Landscape effects on the spread of invasive species. Curr. Landsc. Ecol. Rep. 1, 107-114 (2016).

35. Stohlgren, T. J. et al. Species richness and patterns of invasions in plants, birds and fishes in the United States. Biol. Invasions $\mathbf{8}$, 427-444 (2006).

36. Chytrý, M. et al. Habitat invasions by alien plants: a quantitative comparison among Mediterranean, subcontinental and oceanic regions of Europe. J. Appl. Ecol. 45, 448-458 (2008).

37. Pyšek, P. et al. Disentangling the role of environmental and human pressures on biological invasions across Europe. Proc. Natl. Acad. Sci. 107(27), 12157-12162 (2010).

38. Szymura, T. H., Szymura, M., Zając, M. \& Zając, A. Effect of anthropogenic factors, landscape structure, land relief, soil and climate on risk of alien plant invasion at regional scale. Sci. Total Environ. 626, 1373-1381 (2018).

39. Marini, L. et al. Alien and native plant life-forms respond differently to human and climate pressures. Global Ecol. Biogeogr. 21, 534-544 (2012).

40. Buccheri, M., Boscutti, F., Pellegrini, E. \& Martini, F. Alien flora in Friuli Venezia Giulia. Gortania 40, 7-78 (2019) (in Italian). 
41. Barros, A. \& Pickering, C. M. Non-native plant invasion in relation to tourism use of Aconcagua Park, Argentina, the highest protected area in the Southern Hemisphere. Mt. Res. Dev. 34(1), 13-26 (2014).

42. Boscutti, F. et al. Conservation tillage affects species composition but not species diversity: a comparative study in northern Italy. Environ. Manag. 55(2), 443-452 (2015).

43. Galasso, G. et al. An updated checklist of the vascular flora alien to Italy . Plant Biosyst Int. J. Deal. Asp. Plant Biol. 152, 556-592 (2018).

44. Gao, T. et al. Evaluating the feasibility of using candidate DNA barcodes in discriminating species of the large Asteraceae family. BMC Evol. Biol. 10(1), 324 (2010).

45. Gallagher, R. V., Randall, R. P. \& Leishman, M. R. Trait differences between naturalized and invasive plant species independent of residence time and phylogeny. Conserv. Biol. 29(2), 360-369 (2015).

46. Hamilton, M. A. et al. Life-history correlates of plant invasiveness at regional and continental scales. Ecol. Lett. 8, 1066-1074 (2005).

47. Ahern, R. G., Landis, D. A., Reznicek, A. A. \& Schemske, D. W. Spread of exotic plants in the landscape: the role of time, growth habit, and history of invasiveness. Biol. Invasions 12(9), 3157-3169 (2010).

48. Ohlemüller, R., Walker, S. \& Bastow Wilson, J. Local vs regional factors as determinants of the invasibility of indigenous forest fragments by alien plant species. Oikos 112, 493-501 (2006).

49. Zhu, L., Sun, O. J., Sang, W., Li, Z. \& Ma, K. Predicting the spatial distribution of an invasive plant species (Eupatorium adenophorum) in China. Landsc. Ecol. 22(8), 1143-1154 (2007).

50. Timsina, B., Shrestha, B. B., Rokaya, M. B. \& Münzbergová, Z. Impact of Parthenium hysterophorus L. invasion on plant species composition and soil properties of grassland communities in Nepal. Flora-Morphol. Distrib. Funct. Ecol. Plants 206(3), 233-240 (2011).

51. Francis, A. P. \& Currie, D. J. A globally consistent richness-climate relationship for angiosperms. Am. Nat. 161, 523-536 (2003).

52. Currie, D. J. et al. Predictions and tests of climate-based hypotheses of broad-scale variation in taxonomic richness. Ecol. Lett. 7, 1121-1134 (2004)

53. Tordoni, E. et al. Climate and landscape heterogeneity drive spatial pattern of endemic plant diversity within local hotspots in South-Eastern Alps. Perspect. Plant. Ecol. 43, 125512 (2020).

54. Alpert, P., Bone, E. \& Holzapfel, C. Invasiveness, invisibility and the role of environmental stress in the spread of non-native plants. Perspect. Plant Ecol. Evol. Syst. 3, 52-66 (2000).

55. Richardson, D. \& Pyšek, P. Plant invasions: merging the concepts of species invasiveness and community invasibility. Prog. Phys. Geogr. 30, 409 (2006).

56. Marini, L. et al. Beta diversity and alien plant invasion. Global Ecol. Biogeogr. 22, 450-460 (2013).

57. Haider, S. et al. Mountain roads and non-native species modify elevational patterns of plant diversity. Global Ecol. Biogeogr. 27, 667-678 (2018).

58. Qian, H. \& Ricklefs, R. E. The role of exotic species in homogenizing the North American flora. Ecol. Lett. 9(12), 1293-1298 (2006).

59. Roy, D. B., Hill, M. O. \& Rothery, P. Effects of urban land cover on the local species pool in Britain. Ecography 22, 507-515 (1999).

60. McIntyre, S. \& Lavorel, S. Predicting richness of native, rare, and exotic plants in response to habitat and disturbance variables across a variegated landscape. Conserv. Biol. 8(2), 521-531 (1994).

61. Aikio, S., Duncan, R. P. \& Hulme, P. E. The vulnerability of habitats to plant invasion: disentangling the roles of propagule pressure, time and sampling effort. Glob. Ecol. Biogeogr. 21, 778-786 (2012).

62. Cilliers, S. S., Williams, N. S. G. \& Barnard, F. J. Patterns of exotic plant invasions in fragmented urban and rural grasslands across continents. Landsc. Ecol. 23, 1243-1256 (2008).

63. Pyšek, P. Alien and native species in Central European urban floras: a quantitative comparison. J. Biogeogr. 25, 155-163 (1998).

64. Hulme, P.E. Nursery crimes: agriculture as victim and perpetrator in the spread of invasive species. Crop Sci. Technol. 733-740 (2005).

65. McDougall, K. L. et al. Running off the road: roadside non-native plants invading mountain vegetation. Biol. Invasions 20, 3461$3473(2018)$.

66. Groves, R. H., Austin, M. P. \& Kaye, P. E. Competition between Australian native and introduced grasses along a nutrient gradient. Austral. Ecol. 28, 491-498 (2003).

67. Dupouey, J. L., Dambrine, E., Laffite, J. D. \& Moares, C. Irreversible impact of past land use on forest soils and biodiversity. Ecology 83(11), 2978-2984 (2002).

68. Foster, D. et al. The importance of land-use legacies to ecology and conservation. Bioscience 53(1), 77-88 (2003).

69. Spooner, P. G. \& Lunt, I. D. The influence of land-use history on roadside conservation values in an Australian agricultural landscape. Aust. J. Bot. 52, 445-458 (2004).

70. Lindborg, R., Plue, J., Andersson, K. \& Cousins, S. A. O. Function of small habitat elements for enhancing plant diversity in different agricultural landscapes. Biol. Conserv. 169, 206-213 (2014).

71. Dorrough, J. \& Scroggie, M. P. Plant responses to agricultural intensification. J. Appl. Ecol. 45(4), 1274-1283 (2008).

72. Stoate, C. et al. Ecological impacts of arable intensification in Europe. J. Environ. Manag. 63, 337-365 (2001).

73. Deutschewitz, K., Lausch, A., Kühn, I. \& Klotz, S. Native and alien plant species richness in relation to spatial heterogeneity on a regional scale in Germany. Glob. Ecol. Biogeogr. 12(4), 299-311 (2003).

74. Grime, J. P. Plant Strategies and Vegetation Processes (Wiley, Chichester, 1979).

75. Molino, J. F. \& Sabatier, D. Tree diversity in tropical rain forests: a validation of the intermediate disturbance hypothesis. Science 294(5547), 1702-1704 (2001).

76. Tscharntke, T., Klein, A. M., Kruess, A., Steffan-Dewenter, I. \& Thies, C. Landscape perspectives on agricultural intensification and biodiversity-ecosystem service management. Ecol. Lett. 8, 857-874 (2005).

77. Carulli, G.B. Carta geologica del Friuli Venezia Giulia (scale 1:150000) (Geological Map of Friuli Venezia Giulia, scale 1:150000). Ed. S.E.L.C.A. Firenze (2006).

78. Gortani, L. \& Gortani, M. Flora friulana con particolare riguardo alla Carnia. Udine: ed. Tipografia Doretti (in Italian) (1906).

79. Bonfanti, P., Fregonese, A. \& Sigura, M. Landscape analysis in areas affected by land consolidation. Landsc. Urban Plan. 37(1-2), 91-98 (1997).

80. Ehrendorfer, F. \& Hamann, U. Vorschläge zu einer floristischen Kartierung von Mitteleuropa. Berichte der Deutschen Botanischen Gesellschaft (in German) (1965).

81. Bartolucci, F. et al. An updated checklist of the vascular flora native to Italy . Plant Biosyst. Int. J. Deal. Asp. Plant Biol. 152, 179-303 (2018).

82. Engelen, G., Lavalle, C., Barredo, J. I., Van der Meulen, M. \& White, R. The moland modelling framework for urban and regional land-use dynamics. In Modelling Land-Use Change: Progress and Applications (eds Koomen, E. et al.) 297-320 (Springer, Berlin, 2007).

83. Quantum GIS Development Team. QGIS Geographic Information System. Open Source Geospatial Foundation Project (2017).

84. Dormann, C. F. et al. Collinearity: a review of methods to deal with it and a simulation study evaluating their performance. Ecography 36, 27-46 (2013).

85. Fox, J. \& Weisberg, S. An R Companion to Applied Regression (Sage Publications, Thousand Oaks, 2011). 
86. Dormann, C. F. et al. Effects of landscape structure and land-use intensity on similarity of plant and animal communities. Glob. Ecol. Biogeogr. 16, 774-787 (2007).

87. Pinheiro, J. C. \& Bates, D. M. Mixed-Effects Models in S and S-Plus (Springer, Berlin, 2000).

88. R Core Team R. A Language and Environment for Statistical Computing (R Foundation for Statistical Computing, Vienna, 2019).

89. Barton, K. MuMIn: Multi-model inference. R package version 1.15.6 (2016).

90. Pinheiro, J., Bates, D., Debroy, S., Sarkar, D. \& R core team nlme: Linear and Nonlinear Mixed Effects Models. R package version $3.1-131(2017)$.

91. Burham, K. P. \& Anderson, D. R. Model Selection and Multimodel Inference-A Pratical Information-Theoretic Approach (Springer , Berlin, 2002).

\section{Acknowledgements}

This research was funded by the Regione Autonoma Friuli Venezia Giulia, Italy. Authors would like to thank all contributors to field data collection and in particular Gianfranco Bertani, Adriano Bruna, Antonino Danelutto, Roberto Pavan and Claudio Peruzovich. We thank Anna Carpanelli and Marco Valecic for the profitable collaboration during the research project.

\section{Author contributions}

FB conceived the idea and designed the experiment. FM collected and coordinated the collection of the field data. FB and MB collected available data from public datasets and repositories. EP and FB performed the data analysis and led the writing of the manuscript. All authors contributed critically to the final manuscript and gave their approval for publication.

\section{Competing interests}

The authors declare no competing interests.

\section{Additional information}

Supplementary Information The online version contains supplementary material available at https://doi.org/ 10.1038/s41598-021-87806-7.

Correspondence and requests for materials should be addressed to E.P.

Reprints and permissions information is available at www.nature.com/reprints.

Publisher's note Springer Nature remains neutral with regard to jurisdictional claims in published maps and institutional affiliations.

(c) (i) Open Access This article is licensed under a Creative Commons Attribution 4.0 International License, which permits use, sharing, adaptation, distribution and reproduction in any medium or format, as long as you give appropriate credit to the original author(s) and the source, provide a link to the Creative Commons licence, and indicate if changes were made. The images or other third party material in this article are included in the article's Creative Commons licence, unless indicated otherwise in a credit line to the material. If material is not included in the article's Creative Commons licence and your intended use is not permitted by statutory regulation or exceeds the permitted use, you will need to obtain permission directly from the copyright holder. To view a copy of this licence, visit http://creativecommons.org/licenses/by/4.0/.

(C) The Author(s) 2021 